\title{
The 75-g Oral Glucose Tolerance Test: Effect on Splanchnic Metabolism of Substrates and Pancreatic Hormone Release in Healthy Man
}

\author{
W.K. Waldhäusl, S. Gasić, P. Bratusch-Marrain and P. Nowotny \\ Division of Clinical Endocrinology and Diabetes Mellitus, I. Medizinische Universitätsklinik, Vienna, Austria
}

Summary. To determine the effect of the $75 \mathrm{~g}$ oral glucose tolerance test on carbohydrate and lipid metabolism, the splanchnic exchange of glucose, lactate, pyruvate, non-esterified fatty acids, $\beta$-hydroxybutyrate and acetoacetate as well as the release of insulin, C-peptide, glucagon and pancreatic polypeptide were evaluated in eight healthy male volunteers in the basal state and for 150 min following glucose ingestion. Oral glucose loading was followed by a rapid rise in splanchnic output of glucose (mean $\pm \mathrm{SEM} ; 154 \pm 12 \mathrm{mmol} / 150 \mathrm{~min}$ ), pyruvate $(1.2 \pm 1.2 \mathrm{mmol} / 150 \mathrm{~min})$ and lactate $(8.6 \pm 2.0$ $\mathrm{mmol} / 150 \mathrm{~min}$ ), whereas there were reductions in the splanchnic uptake of non-esterified fatty acids $(-10.7 \pm 4.4$ $\mathrm{mmol} / 150 \mathrm{~min}$ ) and the splanchnic output of $\beta$-hydroxybutyrate $(-4.8 \pm 3.3 \mathrm{mmol} / 150 \mathrm{~min})$ and acetoacetate $(-3.0 \pm 1.2$ $\mathrm{mmol} / 150 \mathrm{~min})$. In parallel, splanchnic output of insulin $(12.3 \pm 2.7 \mathrm{nmol} / 150 \mathrm{~min}), \quad$-peptide $\quad(36.1 \pm 5.0 \mathrm{nmol} /$ $150 \mathrm{~min}$ ) and transiently of pancreatic polypeptide rose, whereas that of glucagon fell $(-0.58 \pm 0.21 \mathrm{nmol} / 150 \mathrm{~min})$. Even at $150 \mathrm{~min}$ after glucose ingestion, splanchnic ouptut and arterial concentrations of glucose, lactate, insulin and Cpeptide were still above their respective basal values while those of non-esterified fatty acids and glucagon were reduced. Taking into account the partial suppression of endogenous glucose production by ingested glucose it is concluded that, in normal postabsortive man, only $49-63 \%$ of a $75 \mathrm{~g}$ oral glucose load is retained by the splanchnic bed during the first $150 \mathrm{~min}$, the rest being available for non-hepatic tissues. Since typical metabolic responses to oral glucose loading were maintained up to $150 \mathrm{~min}$ after glucose ingestion, it appears that glucose absorption from the gut was not yet complete within this time. This finding partially jeopardizes the interpretation of calculated post-prandial hepatic glucose uptake for short observation periods.

Key words: Standard oral glucose tolerance test, splanchnic glucose output, splanchnic glucose retention, insulin production rate, non-esterified fatty acids, glucagon, pancreatic polypeptide.
Recent work using the hepatic venous catheter technique in normal man described the effects of different amounts of ingested glucose on insulin production rate [1] and splanchnic carbohydrate metabolism [2, 3]. No data are, however, available on the splanchnic exchange of substrates and hormones during the new $75 \mathrm{~g}$ oral glucose tolerance test, which has been recommended by the World Health Organization [4]. This study was consequently undertaken to investigate the effect of the proposed $75 \mathrm{~g}$ standard glucose load on splanchnic exchange of glucose and lipid metabolites as well as of released pancreatic hormones. This evaluation of splanchnic substrate metabolism and hormone release following standardized oral glucose loading is of considerable interest as the liver is thought to be the primary and most sensitive target organ of insulin action as compared to peripheral tissue $[5,6]$. Furthermore, the hepatic bed has been assumed to exert a strong impact on glucose concentration in peripheral blood by con- trolling splanchnic glucose escape as only a small amount (around 15\%) of a $100 \mathrm{~g}$ glucose load seems to be released by the splanchnic bed for utilization by peripheral tissues in healthy man within a $3 \mathrm{~h}$ period [3].

\section{Subjects and Methods}

\section{Subjects}

Subjects were 12 male volunteers between 19 and 32 years of age. All were within $10 \%$ of ideal body weight $(101.0 \pm 2.7 \%$, mean \pm SEM, as determined by Metropolitan Life Insurance Tables, 1959). None was diabetic or gave a history of liver disease as indicated by normal blood laboratory tests and oral glucose tolerance test $(100 \mathrm{~g})$. All subjects were asked to ingest a weight-maintaining diet containing $250-300 \mathrm{~g}$ of carbohydrate for at least 3 days before the study. The nature, purpose and possible risks of the study were carefully explained to all subjects before obtaining their consent to participate. The protocol of the study was approved by the Ethical Committee of the hospital. 
Table 1. Net splanchnic output of metabolites and of pancreatic hormones in the basal state, during 150 min after ingestion of $75 \mathrm{~g}$ glucose and above basal in eight healthy men

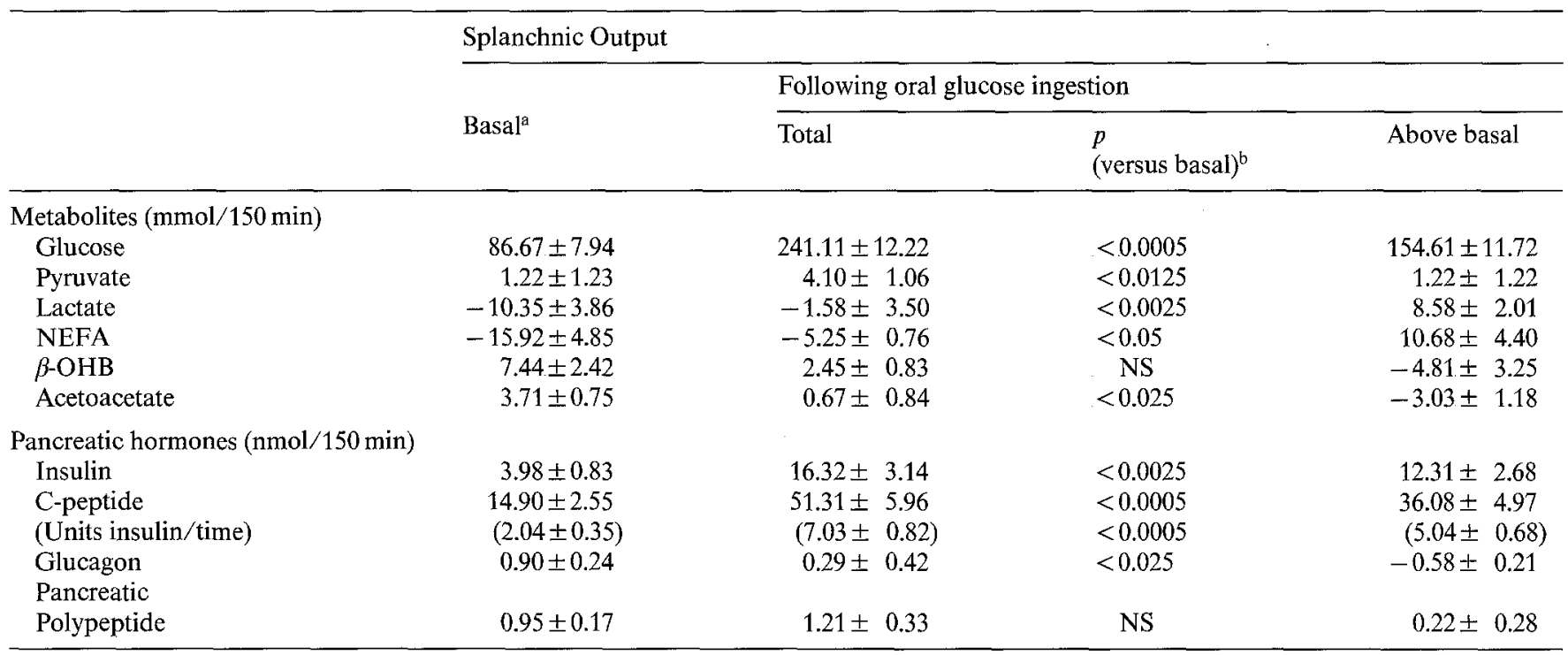

Results are mean \pm SEM

a Basal values are calculated from the mean of five observations in each subject during 30 min preceding glucose ingestion and expressed per $150 \mathrm{~min}$

${ }^{b}$ Denotes the significance of differences between total splanchnic output and the respective basal values times $150 \mathrm{~min}$

\section{Procedures}

Studies were performed with subjects in the recumbent position after an overnight fast $(14-16 \mathrm{~h})$. Catheters were inserted percutaneously into a peripheral vein, a femoral artery and through a femoral vein into a right-sided hepatic vein under fluoroscopic control as described previously [1, 2]. After the catheters were in place, arterial and hepatic venous blood was drawn at $7.5 \mathrm{~min}$ intervals both for a $30 \mathrm{~min}$ basal control period and for $150 \mathrm{~min}$ after ingestion of either $75 \mathrm{~g}$ glucose ( $n=8$; glucose monohydrate $82.5 \mathrm{~g} / 195 \mathrm{ml}$ corresponding to $75 \mathrm{~g}$ glucose; Boehringer-Mannheim, Mannheim, FRG) or $200 \mathrm{ml}$ of water $(n=4)$. The total volume of blood obtained from each subject was $470 \mathrm{ml}$.

Methods for determination of estimated hepatic blood and plasma flow by means of the hepatic venous catheter technique using a primed constant infusion of indocyanine green dye $[7,8]$ have been described previously [1]. To avoid turbidity $5 \%$ sodium deoxycholate (Fluka, Buchs, Switzerland) was passed through a millipore filter $(0.45 \mu)$ and added to plasma before the measurement of indocyanine green dye [9]. Measurements of glucose were performed in whole blood by the hexokinase reaction, whereas lactate, pyruvate, nonesterified fatty acids (NEFA), $\beta$-hydroxybutyrate $(\beta$-OHB) and acetoacetate were analyzed enzymatically in plasma [10]. Insulin, C-peptide, glucagon and human pancreatic polypeptide were determined as previously reported $[1,11,12]$.

Values for substrates, insulin $(1 \mathrm{mU} / 1=7.3 \mathrm{pmol} / 1)$, C-peptide $(1 \mathrm{ng} / \mathrm{ml}=331 \mathrm{pmol} / \mathrm{l})$, glucagon $(1 \mathrm{pg} / \mathrm{ml}=0.287 \mathrm{pmol} / \mathrm{l})$ and $\mathrm{hu}-$ man pancreatic polypeptide $(1 \mathrm{pg} / \mathrm{ml}=0.238 \mathrm{pmol} / \mathrm{l})$ were expressed in molarities. The following molecular weights were used for the calculations of molarities of pancreatic hormones: insulin 5734 [13], Cpeptide 3021 [14], glucagon 3485 [15] and pancreatic polypeptide 4200 daltons [16].

Splanchnic exchange of substrates and hormones was calculated from the transsplanchnic (hepatic venous - arterial) concentration difference multiplied by the estimated hepatic blood or plasma flow, as appropriate; a positive splanchnic balance indicates a net output, a negative one net splanchnic uptake. Total output from the splanchnic bed for all variables during the $150 \mathrm{~min}$ following glucose ingestion was calculated by the trapezoidal rule as the area under the curve. Insulin production rate was derived from splanchnic C-peptide output
[1]. Hepatic fractional extraction (\%) of immunoreactive insulin (IRI), indicating the relative share of insulin retained by the liver [17], was estimates as $\left(\frac{\mathrm{P}-\mathrm{HV}}{\mathrm{P}}\right)$ where $\mathrm{HV}$ represents hepatic venous and $\mathrm{P}$ prehepatic, i.e. portal and hepatic arterial concentration of insulin to which the liver cells are exposed. $P$ was estimated as the sum of arterial insulin concentrations plus the differences in hepatic venous and arterial concentrations of $\mathrm{C}$-peptide, both expressed in molarities. This calculation appears feasible as hepatic extraction of C-peptide is negligible [18]. Hepatic IRI uptake (pmol/min) was calculated as $\left(\mathrm{P}-\mathrm{HV}_{\mathrm{IRI}}\right) \times$ estimated hepatic plasma flow. The hepatic clearance rate of IRI was calculated as the hepatic uptake divided by the estimated prehepatic insulin concentration [P] and expressed as milliliters per minute. Splanchnic fractional extraction of NEFA was calculated as the percentage of arterio-hepatic venous differences from arterial concentration.

All data in the text, tables and figures are presented as mean \pm SEM. The paired Student's t-test was employed for statistical analysis [20].

\section{Results}

\section{Splanchnic Output of Substrates}

The effect of a $75 \mathrm{~g}$ oral glucose load on the splanchnic output of glucose over $150 \mathrm{~min}$, as well as on that of some gluconeogenic substrates and their oxidation products, is presented in Table 1 per $150 \mathrm{~min}$. Before glucose ingestion glucose, pyruvate, $\beta$-OHB and acetoacetate were mostly released from the splanchnic bed, whereas lactate and NEFA were taken up. Following oral glucose loading splanchnic output rose significantly above basal for glucose, pyruvate and lactate, thereby transiently reversing splanchnic lactate uptake (Fig. 1) into a net output. Splanchnic uptake of NEFA was reduced after glucose ingestion by 10.68. 

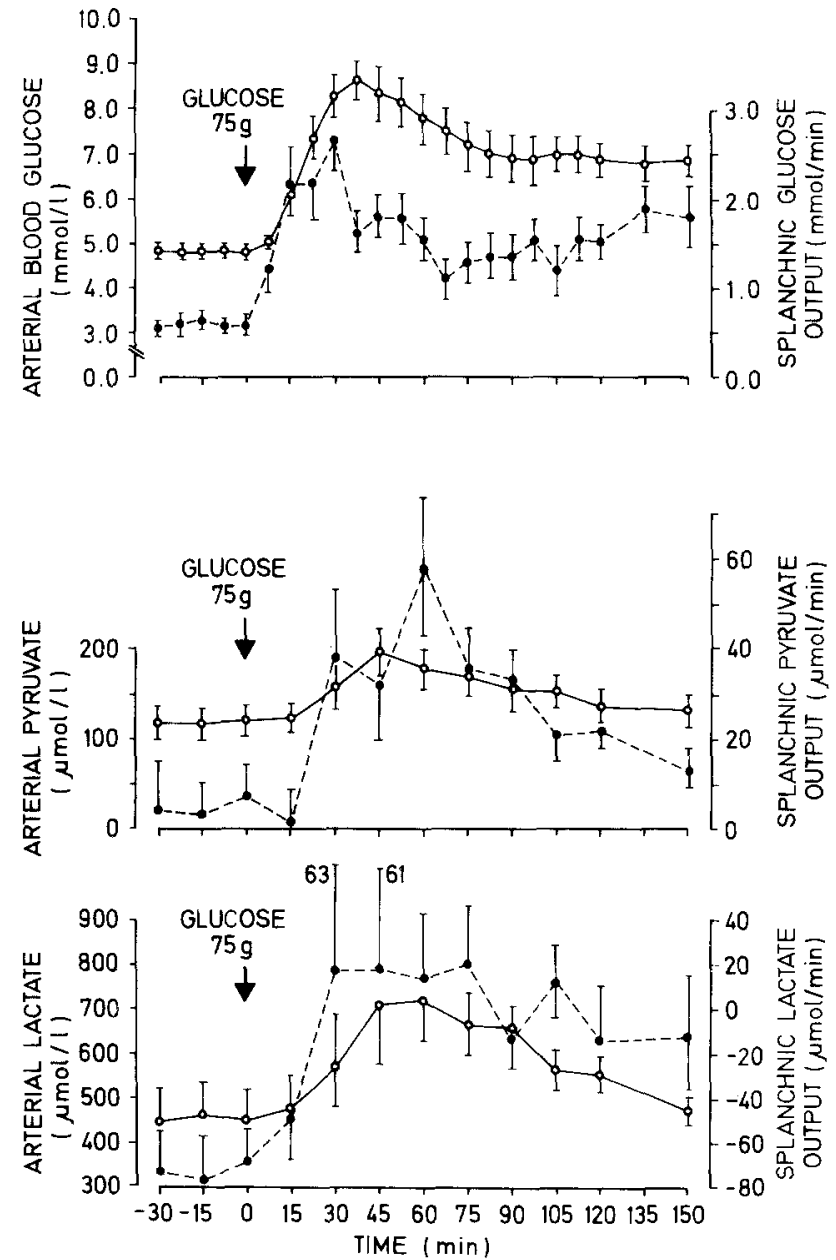

Fig. 1. Arterial concentrations $\left(\mathrm{O}_{-}-\mathrm{O}\right)$ and splanchnic output $(\bullet--\bullet)$ of blood glucose, pyruvate and lactate in the basal state and after ingestion of $75 \mathrm{~g}$ glucose in eight healthy men. Values are mean $\pm \mathrm{SEM}$

$4.40 \mathrm{mmol} / 150 \mathrm{~min}$ as was splanchnic output of acetoacetate. This was accompanied by a fall in splanchnic fractional extraction of NEFA from a basal value of $17 \pm 3 \%$ to a nadir of $-14 \pm 7 \%$ at $96 \pm 6 \min (p<$ $0.0025)$. No significant change was seen in the splanchnic exchange of $\beta$-OHB during $150 \mathrm{~min}$ following glucose loading. Total splanchnic glucose output was $43.4 \pm 2.2 \mathrm{~g} / 150 \mathrm{~min}$ after glucose ingestion, which translates into a minimal post-prandial splanchnic retention of $31.8 \pm 2.2 \mathrm{~g} / 150 \mathrm{~min}$, whereas splanchnic glucose output above basal was $27.8 \pm 2.1 \mathrm{~g} / 150 \mathrm{~min}$.

Before glucose ingestion values of arterial glucose, pyruvate and lactate fluctuated only to a small extent, but rose to mean individual peak levels of $9.0 \pm 0.3$ $\mathrm{mmol} / 1$ for glucose at $53 \pm 15 \mathrm{~min}$, of $204 \pm 24 \mu \mathrm{mol} / 1$ for pyruvate at $64 \pm 8 \mathrm{~min}$, and of $789 \pm 102 \mu \mathrm{mol} / 1$ for lactate at $69 \pm 9 \mathrm{~min}$ (Fig. 1). These rises in arterial concentration were paralleled by an increase in splanchnic output of the respective variables, which reached their maximal values of $2.8 \pm 0.3 \mathrm{mmol} / \mathrm{min}$ (glucose) at $55 \pm 18 \mathrm{~min}$, of $66 \pm 14 \mu \mathrm{mol} / \mathrm{min}$ (pyruvate) at $64 \pm$ $9 \mathrm{~min}$ and of $81 \pm 24 \mu \mathrm{mol} / \mathrm{min}$ (lactate) at $64 \pm 11 \mathrm{~min}$.
It is of note that, $150 \mathrm{~min}$ after glucose ingestion, values were still in part significantly above their respective basal values for arterial blood glucose $(\Delta+2.1 \pm$ $0.3 \mathrm{mmol} / \mathrm{l}, p<0.0005)$, pyruvate $(\Delta+13 \pm 13 \mu \mathrm{mol} / \mathrm{l}$, NS) and lactate $(\Delta+26 \pm 60 \mu \mathrm{mol} / \mathrm{l}, \mathrm{NS})$ as well as for the splanchnic output of glucose $(\Delta+1.13 \pm$ $0.32 \mathrm{mmol} / \mathrm{min}, \quad p<0.01), \quad$ pyruvate $(\Delta+8 \pm$ $9 \mu \mathrm{mol} / \mathrm{min}, \mathrm{NS})$ and lactate $(\Delta+58 \pm 24 \mu \mathrm{mol} / \mathrm{min}$, $p<0.025)$. Mean arterial concentrations of NEFA fell from basal values of $720 \pm 106$ to $198 \pm 24 \mu \mathrm{mol} / 1(p<$ 0.0025 ) at $150 \mathrm{~min}$ after glucose ingestion, whereas those of acetoacetate (basal, $370 \pm 21 \mu \mathrm{mol} / 1$ ) and $\beta$ OHB (basal, $294 \pm 62 \mu \mathrm{mol} / \mathrm{l}$ ) stayed within their respective basal ranges.

\section{Splanchnic Output of Pancreatic Hormones (Table 1)}

Splanchnic output of insulin (basal, $3.98 \pm 0.83 \mathrm{nmol} /$ $150 \mathrm{~min}$ ) and C-peptide (basal, $14.90 \pm 2.55 \mathrm{nmol} /$ $150 \mathrm{~min}$ ) rose about fourfold above basal following glucose loading, whereas splanchnic output of glucagon (basal, $0.90 \pm 0.24 \mathrm{nmol} / 150 \mathrm{~min}$ ) was reduced by $68 \%$. No change occurred in total splanchnic output of pancreatic polypeptide. The observed increase above basal in splanchnic C-peptide output reflects an insulin production rate of $5.04 \pm 0.68 \mathrm{U} / 150 \mathrm{~min}$, which corresponds to a total glucose output of $43.4 \pm 2.2 \mathrm{~g} / 150 \mathrm{~min}$.

Hormone concentrations in hepatic venous blood were consistently greater than in arterial blood (Table 2). Following ingestion of $75 \mathrm{~g}$ glucose mean arterial insulin and C-peptide concentrations of individual peak levels rose to $427 \pm 70 \mathrm{pmol} / 1$ at $52 \pm 15 \mathrm{~min}$, and to $2248 \pm 185 \mathrm{pmol} / 1$ at $79 \pm 11 \mathrm{~min}$, respectively. The observed arterial C-peptide concentrations were related to splanchnic C-peptide output $(p<0.001)$ and thereby to insulin production rate. Serum concentrations of pancreatic polypeptide rose only transiently at 15 to $45 \mathrm{~min}(p<0.0125$ to $<0.0025)$ and reached individual peak levels of $70 \pm 12 \mathrm{pmol} / 1$ at $21 \pm 3 \mathrm{~min}$ after glucose ingestion. In contrast, plasma concentrations of glucagon fell by $53 \%$ to $10 \pm 1 \mathrm{pmol} / \mathrm{l}$, reaching their nadir at $87 \pm 16 \mathrm{~min}$. Elevated levels of insulin and Cpeptide, as well as reduced values of plasma glucagon, were still observed at $150 \mathrm{~min}$ after glucose ingestion.

\section{Estimated Hepatic Blood Flow and Handling of Insulin Across the Hepatic Bed}

Estimated hepatic blood flow in the basal state was $1222 \pm 145 \mathrm{ml} / \mathrm{min}$ and rose to individual peak values of $1995 \pm 249 \mathrm{ml} / \mathrm{min}$ at $38 \pm 11 \mathrm{~min}$ after glucose ingestion. This change was paralleled by a rise in estimated hepatic plasma flow from a basal value of $696 \pm 73 \mathrm{ml} /$ min to a peak of $1187 \pm 137 \mathrm{ml} / \mathrm{min}$ within 7.5 to 112.5 min (Table 2).

Stimulation of insulin production rate by glucose ingestion (Table 3 ) was accompanied by a four- to fivefold rise in calculated hepatic insulin uptake up to $150 \mathrm{~min}$ 
Table 2. Effect of a $75 \mathrm{~g}$ oral glucose load on arterial and hepatic venous concentrations of insulin, C-peptide, glucagon and pancreatic polypeptide and estimated hepatic plasma flow in eight healthy men

\begin{tabular}{|c|c|c|c|c|c|c|c|c|c|c|c|}
\hline & \multirow[b]{2}{*}{ Basal $^{\mathrm{a}}$} & \multicolumn{10}{|l|}{ Time (min) } \\
\hline & & 15 & 30 & 45 & 60 & 75 & 90 & 105 & 120 & 135 & 150 \\
\hline \multicolumn{12}{|l|}{ Insulin (pmol/l) } \\
\hline Hepatic venous & $95 \pm 15$ & $350 \pm 88$ & $548 \pm 95$ & $475 \pm 80$ & $102 \pm 102$ & $423 \pm 110$ & $350 \pm 66$ & $380 \pm 66$ & $343 \pm 73$ & $358 \pm 73$ & $387 \pm 73$ \\
\hline \multicolumn{12}{|l|}{ C-peptide (pmol/1) } \\
\hline Arterial & $635 \pm 79$ & $1079 \pm 192$ & $1737 \pm 245$ & $1790 \pm 136$ & $1821 \pm 139$ & $1834 \pm 199$ & $1797 \pm 139$ & $1840 \pm 113$ & $1933 \pm 99$ & $1917 \pm 152$ & $1833 \pm 119$ \\
\hline \multicolumn{12}{|l|}{ Glucagon (pmol/1) } \\
\hline Arterial & $20 \pm 2$ & $19 \pm 3$ & $15 \pm 1$ & $12 \pm 1$ & $13 \pm 2$ & $11 \pm$ & $12 \pm \quad 1$ & $12 \pm 1$ & $12 \pm$ & - & $13 \pm$ \\
\hline Hepatic venous & $34 \pm 4$ & $29 \pm 3$ & $23 \pm 3$ & $20 \pm \quad 2$ & $18 \pm \quad 2$ & $18 \pm$ & $17 \pm \quad 2$ & $16 \pm 2$ & $17 \pm$ & - & $15 \pm 2^{2}$ \\
\hline \multicolumn{12}{|c|}{$\begin{array}{l}\text { Pancreatic } \\
\text { polypeptide }(\mathrm{pmol} / \mathrm{l})\end{array}$} \\
\hline Arterial & $27 \pm 6$ & $64 \pm 12$ & $49 \pm 7$ & $36 \pm 4$ & $28 \pm 4$ & $28 \pm$ & $28 \pm 3$ & $30 \pm$ & $28 \pm$ & - & $28 \pm$ \\
\hline Hepatic venous & $31 \pm 2$ & $87 \pm 15$ & $56 \pm 11$ & $44 \pm 9$ & $31 \pm \quad 5$ & $36 \pm 6$ & $38 \pm 6$ & $38 \pm \quad 2$ & $36 \pm 6$ & - & $31 \pm$ \\
\hline
\end{tabular}

Results expressed as mean \pm SEM

a Basal values represent the mean of five observations in each subject during 30 min preceding glucose loading. $p$ was calculated at 150 min versus the respective basal values:

b. $<0.05$, $^{c}<0.025$, d $<0.01$, e $<0.0025$, and ${ }^{\mathrm{f}}<0.0005$

after glucose ingestion, whereas hepatic fractional extraction of insulin (basal, $53 \pm 2 \%$ ) did not change throughout the study except for a transient fall at 30 min. Mean hepatic insulin clearance rate, which compensates for changes in plasma flow, ranged from 325 to $421 \mathrm{ml} / \mathrm{min}$ and remained unchanged throughout the study.

Control studies in four healthy subjects ingesting $200 \mathrm{ml}$ of water instead of glucose, demonstrated only insigificant changes in mean splanchnic output of glucose $(-10 \%)$, pyruvate $(0 \%)$, lactate $(-12 \%)$, NEFA $(-3 \%), \beta$-OHB $(+20 \%)$ and acetoacetate $(-24 \%)$ during the $150 \mathrm{~min}$ of observation. As far as pancreatic hormones were concerned, a minor and insignificant fall in splanchnic output of insulin $(-11 \%)$ and C-peptide $(-19 \%)$ was seen.

\section{Discussion}

In this study, post-absorptive splanchnic glucose release was accompanied by a splanchnic output of pyruvate, $\beta$-OHB and acetoacetate, whereas lactate and non-esterified fatty acids were retained by the splanchnic bed. Following glucose loading both arterial blood glucose and splanchnic glucose output rose and stayed above basal levels throughout the $150 \mathrm{~min}$ of observation. Simultaneously, splanchnic output of pyruvate and lactate rose significantly above basal, whereas that of acetoacetate was reduced and that of $\beta$-OHB showed no significant change. The described rise in splanchnic NEFA output above basal reflects reduced hepatic uptake of this compound following glucose ingestion.
The observed splanchnic glucose output above basal of $27.8 \pm 2.1 \mathrm{~g} / 150 \mathrm{~min}$ reflecting maximal retention of $63 \%$ or $47.2 \mathrm{~g}$ of ingested glucose by the splanchnic bed as well as the failure of arterial blood glucose to return to baseline levels within $150 \mathrm{~min}$ are in agreement with findings described previously after a $100 \mathrm{~g}$ glucose load [21]. As basal endogenous glucose production (normal, $104 \pm 10 \mathrm{mg} / \mathrm{min}$ ) is reduced by $66 \pm 6 \%$ following a 45 to $96 \mathrm{~g}$ oral glucose load [22] splanchnic glucose retention determined as the difference between the $75 \mathrm{~g}$ of ingested glucose and total splanchnic glucose output (Table 1), corrected for residual glucose production $(5.3 \mathrm{~g} / 150 \mathrm{~min})$, would only amount to $34.9 \mathrm{~g} /$ $150 \mathrm{~min}$. This $49 \%$ retention of ingested glucose could be due both to hepatic glucose uptake and incomplete absorption of glucose from the gut, which is known to last for at least $210 \mathrm{~min}$ [23]. Incomplete absorption instead of increased hepatic glucose retention as an additional cause of the $49-63 \%$ splanchnic retention of ingested glucose per $150 \mathrm{~min}$ would be in line with the observation that in normal man about $90 \%$ of an $100 \mathrm{~g}$ oral glucose load is absorbed and passes through the liver within 180 to $240 \mathrm{~min}$ [22]. Our findings are also in contrast to the contention that the liver was the preferred site of oral glucose deposition [24] and to the described earlier decline of arterial glucose and splanchnic glucose output to baseline values by 120 to $165 \mathrm{~min}$ after ingestion of $100 \mathrm{~g}$ glucose [25]. The latter observation may be due in part to the broad range of gastric emptying time (40 to $85 \mathrm{~min}$; [26]) and to pulsatile gastric emptying. The minimal share of ingested glucose escaping the splanchnic bed above basal after ingestion of $75 \mathrm{~g}$ glucose and thus being available for non-insulin 
Table 3. Effect of a $75 \mathrm{~g}$ oral glucose load on the fate of insulin across the splanchnic bed in eight healthy men

\begin{tabular}{|c|c|c|c|c|c|c|c|c|c|c|c|}
\hline & \multirow[b]{2}{*}{ Basal $^{a}$} & \multicolumn{10}{|c|}{ Time (min) } \\
\hline & & 15 & 30 & 45 & 60 & 75 & 90 & 105 & 120 & 135 & 150 \\
\hline $\begin{array}{l}\text { Insulin production rate } \\
\text { (pmol/min) }\end{array}$ & $100 \pm 17$ & $340 \pm 97^{c}$ & $404 \pm 37^{1}$ & $488 \pm 73^{f}$ & $462 \pm 78^{\mathrm{e}}$ & $378 \pm 102^{\mathrm{d}}$ & $334 \pm 51^{\mathrm{e}}$ & $352 \pm 62^{d}$ & $249 \pm 84$ & $298 \pm 51^{d}$ & $478 \pm 126^{\mathrm{d}}$ \\
\hline $\begin{array}{l}\text { Hepatic uptake } \\
(\mathrm{pmol} / \mathrm{min})\end{array}$ & $79 \pm 14$ & $163 \pm 35^{\mathrm{c}}$ & $244 \pm 38^{\mathrm{d}}$ & $340 \pm 43^{f}$ & $318 \pm 74^{\mathrm{d}}$ & $251 \pm 68^{c}$ & $249 \pm 45^{d}$ & $242 \pm 47^{\mathrm{c}}$ & $238 \pm 138$ & $179 \pm 46^{\mathrm{c}}$ & $340 \pm 83^{\mathrm{d}}$ \\
\hline $\begin{array}{l}\text { Hepatic fractional } \\
\text { extraction }(\%)\end{array}$ & $53 \pm 2$ & $41 \pm 6$ & $38 \pm 7^{b}$ & $47 \pm 4$ & $46 \pm 6$ & $45 \pm 6$ & $51 \pm 7$ & $45 \pm 6$ & $37 \pm 10$ & $38 \pm 8$ & $50 \pm \quad 6$ \\
\hline $\begin{array}{l}\text { Hepatic clearance rate } \\
(\mathrm{ml} / \mathrm{min})\end{array}$ & $360 \pm 34$ & $325 \pm 47$ & $360 \pm 63$ & $404 \pm 35$ & $377 \pm 40$ & $335 \pm 55$ & $353 \pm 55$ & $335 \pm 48$ & $294 \pm 78$ & $341 \pm 82$ & $421 \pm 67$ \\
\hline
\end{tabular}

Results expressed as mean \pm SEM

a Basal values represent the mean of five observations in each subject during 30 min preceding glucose loading. $p$ was calculated versus the respective basal values:

b $<0.05,{ }^{c}<0.025$, $d<0.01$, e $<0.0025$ and ${ }^{\mathrm{f}}<0.0005$

dependent tissues such as the brain [27] was $37 \pm 3 \%$ in this study. This compares well with the 31 to $33 \%$ provided by the splanchnic bed per 150 to $180 \mathrm{~min}$ after a $100 \mathrm{~g}$ glucose load in man $[21,28]$ and with the $37 \%$ of ingested glucose entering the general circulation in the rat [29], but contrasts with the $15 \pm 3 \%$ escaping the splanchnic bed after ingestion of $100 \mathrm{~g}$ glucose as reported by others $[3,24]$. The overall error in absorption of ingested glucose introduced by an observation period of only $150 \mathrm{~min}$ as compared to the at least 180-210 min required for complete absorption from the gut may, however, be as little as $12 \%$. This estimate, which can be derived from data obtained during IV and oral glucose loading [23], increases the minimal share of glucose being available for non-hepatic peripheral tissues after a $75 \mathrm{~g}$ glucose load to $49 \%$.

From these findings it is apparent that the term splanchnic glucose retention does not imply that all glucose retained by the splanchnic bed is taken up by the liver. The same splanchnic glucose output estimated by means of the hepatic venous catheter technique not only reflects intestinal glucose absorption, but also includes the effects of splanchnic uptake of absorbed and recirculated glucose as well as suppression of hepatic glucose production; the latter being partially turned off by increases in circulating serum insulin $[6,30,31]$ and possibly also by a rise in portal venous concentrations of blood glucose [32].

In addition, we also examined the effect of a $75 \mathrm{~g}$ glucose load on the splanchnic exchange of lactate, pyruvate, NEFA, $\beta$-OHB and acetoacetate. Our data confirm the well known glucose-dependent rise in plasma lactate and pyruvate concentrations $[33,34]$, which is associated with a rise in splanchnic pyruvate output and a reduction in splanchnic lactate uptake. The increased rate of hepatic glycolysis under these conditions of hyperinsulinaemic hyperglycaemia is reflected by a combined rise in splanchnic lactate and pyruvate output above basal of $9.8 \mathrm{mmol} / 150 \mathrm{~min}$, corresponding to $882 \mathrm{mg}$ glucose or $1.18 \%$ of the ingested glucose load. These alterations in splanchnic release of lactate and pyruvate may be due to the glucose supply offered to the liver or to a change in gluconeogenesis. That peripheral tissues contribute to the rise in lactate concentration [35] has not been substantiated by direct measurements of forearm lactate exchange [36].

NEFA released from triglyceride stores are transported to the liver, which in the dog removes $25 \%$ of offered NEFA [37], corresponding well to the 17\% splanchnic fractional extraction of NEFA seen in this study in healthy men. Following glucose ingestion splanchnic fractional extraction of NEFA fell in parallel with its plasma concentration and even reverted to occasional net splanchnic output at arterial NEFA concentrations below $200 \mu \mathrm{mol} / 1$. Simultaneously, splanchnic NEFA uptake was reduced by approximately $67 \%$, as were arterial NEFA levels, and total splanchnic ketone body output fell by $70 \%$ as less substrate was provided for oxidation [38] (Table 1). The latter effect was most probably due to inhibition of lipolysis by insulin [39], which also directly impairs hepatic ketogenesis [40]. The rise in the $\beta-\mathrm{OHB} /$ acetoacetate ratio, which reflects the intracellular redox state (a rising ratio indicating a more reduced state) after glucose ingestion, may be due to a marked decrease in the splanchnic acetoacetate output or to a preferential uptake of acetoacetate in peripheral tissues. The latter occurs primarily in human muscle [41] and might even be exaggerated by a glucoseinduced rise in serum insulin levels.

Our estimate of post-absorptive insulin release was $14 \pm 2 \mathrm{mU} / \mathrm{min}$ and of the same order of magnitude as the $17 \pm 2 \mathrm{mU} / \mathrm{min}$ [1] or the $23.6 \pm 7.7$ units $/ 24 \mathrm{~h}$, i.e. $16.3 \mathrm{mU} / \mathrm{min}$ [42], reported previously. Total splanchnic C-peptide output following ingestion of $75 \mathrm{~g}$ glucose indicates an insulin production rate of $7.03 \pm 0.82$ units/ $150 \mathrm{~min}$, which is less than the $13.0 \pm 2.0$ units $/ 150 \mathrm{~min}$ released after a $100 \mathrm{~g}$ glucose load [21].

Regarding the fate of insulin across the liver bed, it is of note that, in accordance with previous findings obtained in man with infusion of biosynthetic human insulin [19], hepatic insulin uptake changed in parallel with insulin production rate. This is in line with the pro- 
portional rise in absolute hepatic insulin uptake with increasing portal insulin concentrations shown experimentally in rats [43] and dogs [44]. Following glucose ingestion $(75 \mathrm{~g})$ a transient reduction in hepatic fractional insulin extraction (basal, $53 \pm 2 \%$ ) was observed at $30 \mathrm{~min}$, which was less pronounced than that seen in both healthy subjects and non-insulin-dependent diabetic patients after a $100 \mathrm{~g}$ glucose load [17]. This difference may be due to the smaller amount of glucose ingested in this study. Since hepatic fractional extraction and insulin clearance (basal, $360 \pm 34 \mathrm{ml} / \mathrm{min}$ ), which were both in the previously reported range $[18,19]$, remained mostly unchanged following the $75 \mathrm{~g}$ glucose load, any change in insulin production rate was matched by an appropriate deviation in arterial Cpeptide and insulin concentration.

Furthermore, it is of note that both $120 \mathrm{~min}$ [1] and 150 min after glucose loading concentrations of immunoreactive insulin and C-peptide were still above their respective basal levels. This, as well as the supranormal values of arterial glucose and the associated reduction in arterial glucagon concentration [45], indicates continuing glucose absorption from the gut at the end of the 150 min observation period and thereby also hints at an underestimate of the insulin production rate required for the assimilation of the glucose load. In this context it is of interest that secondary hyperglycaemia at $150 \mathrm{~min}$ after glucose ingestion due to the stress of the experimental procedure was ruled out by the absence of any change in arterial concentrations or splanchnic exchange of substrates and hormones in healthy men ingesting water instead of glucose.

As the basal secretory rate of glucagon is estimated not to exceed 100-150 $\mu \mathrm{g} /$ day [46], the calculated $27 \mu \mathrm{g}$ of basal post-hepatic glucagon release per $24 \mathrm{~h}$ implies $80 \%$ hepatic retention of this hormone. The role of glucagon in determining glucose disposal after glucose ingestion, however, seems remote as neither physiological elevations of plasma glucagon nor its suppression by glucose loading alters glucose tolerance in normal man capable of secreting sufficient amounts of insulin [47] or in diabetic man with appropriate insulin supply [48]. Glucose-induced hypoglucagonaemia may, however, contribute to the reduction in splanchnic ketone production since glucagon is known to promote both hepatic ketogenesis [49] and lipolysis [50]. Arterial concentrations of pancreatic polypeptide were $113 \mathrm{pg} / \mathrm{ml}$ ( $27 \mathrm{pmol} / \mathrm{l}$ ) in the basal state and rose only transiently by $37 \mathrm{pg} / \mathrm{ml} 15 \mathrm{~min}$ after glucose ingestion as described by Floyd et al. [16]. The biological significance of this transient rise is unknown, as it does not affect blood glucose concentrations [16]. The overall post-hepatic production rate of pancreatic polypeptide in the basal state was $38 \mu \mathrm{g} / 24 \mathrm{~h}$, of the same order of magnitude as that of glucagon.

In conclusion, glucose ingestion leads to an increase in splanchnic blood flow and also to a change in multiple endocrine and metabolic variables which interact in concert to control glucose assimilation. From this it appears that among the variables controlling post-prandial glucose metabolism determination of glucose obviously describes just one aspect of the system. Furthermore it is apparent that, $150 \mathrm{~min}$ after glucose ingestion, such key variables of carbohydrate metabolism as splanchnic glucose output and arterial as well as hepatic venous concentrations of glucose, insulin and C-peptide are still above their respective basal values and thus continue to be subject to both variability in glucose absorption and glucose metabolism. These data remind us that glucose absorption from the gut continues beyond $150 \mathrm{~min}$ after glucose ingestion in healthy man and that therefore estimates of hepatic (splanchnic) glucose uptake are subject to error unless the period of observation is extended until absorption of glucose is completed.

Acknowledgements. The authors are indebted for technical assistance to Mrs. A. Hofer, Mrs. E. Nowotny, Mrs. L. Geier, and Mrs. H. Haslinger, and to Dr. K. Kletter for statistical advice. This study was supported by grant No.P 5164 of the 'Fonds zur Förderung der wissenschaftlichen Forschung Österreichs'.

\section{References}

1. Waldhäusl W, Bratusch-Marrain P, Gasić S, Korn A, Nowotny $P$ (1979) Insulin production rate following glucose ingestion estimated by splanchnic C-peptide output in normal man. Diabetologia 17: 221-227

2. Bratusch-Marrain P, Waldhäusl WK, Gasić S, Korn A, Nowotny P (1980) Oral glucose tolerance test: effect of different glucose loads on splanchnic carbohydrate and substrate metabolism in healthy men. Metabolism 29: 289-295

3. Felig P, Wahren J, Hendler R (1975) Influence of oral glucose ingestion on splanchnic glucose and gluconeogenic substrate metabolism in man. Diabetes 24: 468-475

4. WHO (1980) Expert Committee on Diabetes Mellitus. World Health Organisation Technical Report Series 646. World Health Organisation, Geneva

5. Rabinowitz D, Liljenquist JE (1978) Glucose metabolism in intact man: the responsiveness of splanchnic and peripheral tissues to insulin. Metabolism 27: 1832-1838

6. Madison LL (1969) Role of insulin in hepatic handling of glucose. Arch Int Med 123: 284-292

7. Rowell LB, Blackmon JR, Bruce RA (1964) Indocyanine clearance and estimated hepatic blood flow during mild to maximal exercise in upright man. J Clin Invest 43: 1677-1690

8. Bradley SE, Ingelfinger EJ, Bradley GP, Curry JJ (1945) The estimation of hepatic blood flow in man. J Clin Invest 24: 890-897

9. Paschen U, Müller MJ, Seitz HJ (1981) Indocyanine green liver blood flow measurement in the pig. J Clin Chem Clin Biochem 19:797 (Abstract)

10. Bergmeyer HU (ed) (1974) Methoden der enzymatischen Analyse. Verlag Chemie, Weinheim

11. Waldhäusl W, Haydl $H$, Nowotny P (1976) ACTH and cortisol responses to glucagon stimulation. J Clin Endocrinol Metab 43: 675-678

12. Waldhäus1 W, Kleinberger G, Korn A, Dudczak R, Bratusch-Marrain $P$, Nowotny P (1979) Severe hyperglycemia: effects of rehydration on endocrine derangements and blood glucose concentrations. Diabetes 28: 577-584

13. Zahn H, Klostermeyer H (1969) Die Inselzellhormone: Chemie, Struktur und Synthese von Insulin. In: Pfeiffer EF (ed) Handbook of diabetes mellitus, Vol 2. Lehmanns, München, pp 118-147 
14. Oyer PE, Cho S, Patterson JD, Steiner DF (1971) Studies on human proinsulin. Isolation and amino acid sequence of human pancreatic C-peptide. J Biol Chem 246: 1375-1386

15. Bromer WW, Sinn LG, Behrens OK (1957) The amino acid sequence of glucagon. V. Location of amide groups, acid degradation studies and summary of sequential analysis. J Am Chem Soc 79:2807-2810

16. Floyd JC Jr, Fajans SS, Pek S, Chance RE (1977) A newly recognized pancreatic polypeptide; plasma levels in health and disease. Rec Progr Horm Res 33: 519-570

17. Waldhäusl W, Bratusch-Marrain P, Gasić S, Korn A, Nowotny P (1982) Insulin production rate, hepatic insulin retention and splanchnic carbohydrate metabolism after oral glucose ingestion in hyperinsulinaemic Type 2 (non-insulin-dependent) diabetes mellitus. Diabetologia 23: 6-15

18. Bratusch-Marrain P, Waldhäusl W, Gasić S, Hofer A (1983) Hepatic disposal of biosynthetic human insulin and porcine C-peptide in man. Metabolism (in press)

19. Waldhäusl W, Gasić S, Bratusch-Marrain P, Korn A, Nowotny P (1982) Action of biosynthetic human insulin on endogenous insulin release and hepatic insulin disposal in healthy man. Am J Physiol 243: 476-482

20. Statistik (1968) In: Dien K, Lentner C (eds) Dokumenta Geigy, 7th ed. Ciba-Geigy, Basel, pp 146-199

21. Bratusch-Marrain P, Korn A, Waldhäusl WK, Gasić S, Nowotny P (1981) Effect of buformin on splanchnic carbohydrate and substrate metabolism in healthy man. Metabolism 30:946-952

22. Radziuk J, McDonald TJ, Rubenstein D, Dupre J (1978) Initial splanchnic extraction of ingested glucose in normal man. Metabolism 27: 657-669

23. Jacot E, DeFronzo RA, Jequier E, Maeder E, Felber JP (1982) The effect of hyperglycemia, hyperinsulinemia and route of glucose administration on glucose oxidation and storage. Metabolism 31: 922-930

24. Ferrannini E, Wahren J, Felig P, DeFronzo RA (1980) The role of fractional glucose extraction in the regulation of splanchnic glucose metabolism in normal and diabetic man. Metabolism 29: $28-35$

25. Felig P, Wahren J, Hendler R (1978) Influence of maturity onset diabetes on splanchnic glucose balance after oral glucose ingestion. Diabetes 27: 121-126

26. Domstad PA, Kim EE, Coupal JJ, Beihn R, Yonts S, Choy YC, Mandelstam P, DeLand FH (1980) Biologic gastric emptying time in diabetic patients, using $\mathrm{Tc}-99 \mathrm{~m}$ - labelled resin oat meal with and without metoclopramide. J Nucl Med 21: 1098-1100

27. Cahill GF, Herrera MG, Morgan AP, Soeldner JS, Steincke J, Levy PL, Reichard GA, Kipnis DM (1966) Hormone fuel interrelationships during fasting. J Clin Invest 45: 1751-1769

28. Perley MJ, Kipnis DM (1967) Plasma insulin responses to oral and intravenous glucose: studies in normal and diabetic subjects. $J$ Clin Invest 46: 1954-1962

29. Scow RL, Cornfield J (1954) Quantitative relation between oral and intravenous glucose tolerance curves. Am J Physiol 179: $435 \sim 438$

30. Felig P, Wahren J (1971) Influence of endogenous insulin secretion on splanchnic glucose and amino acid metabolism in man. $J$ Clin Invest 50: 1702-1711

31. Steele R, Bishop JS, Altszuler N, Rathgeb I, DeBodo RC (1965) Inhibition by insulin of hepatic glucose production in the normal dog. Am J Physiol 208: 301-306

32. Bergmann RN (1977) Integrated control of hepatic glucose metabolism. Federation Proc 36: 265-270 (1977)
33. Huckabee WE (1958) Relationship of pyruvate and lactate during anaerobic metabolism. I. Effects of infusion of pyruvate, glucose and of hyperventilation. J Clin Invest 37:244-254

34. Doar JWH, Cramp DG, Maw DSI, Seed M, Wynn V (1970) Blood pyruvate and lactate levels during oral and intravenous glucose tolerance tests in diabetes mellitus. Clin Sci 39:259-269

35. Sussman KE (1966) Effect of prolonged fasting on glucose and insulin metabolism in exogenous obesity. Arch Int Med 117: 343-347

36. Jackson RA, Peters N, Advani U, Perry G, Rogers J, Brough WH, Pilkington TRE (1973) Forearm glucose uptake during the oral glucose tolerance test in normal subjects. Diabetes 22 : 442-458

37. Basso LV, Havel RJ (1970) Hepatic metabolism of free fatty acids in normal and diabetic dogs. J Clin Invest 49:537-547

38. McCarry JE, Foster DW (1977) Hormonal control of ketogenesis. Biochemical considerations. Arch Intern Med 137: 495-501

39. Ball EG, Jungas RL (1963) Studies on the metabolism of adipose tissue. XIII. The effect of anaerobic conditions and dietary regime on the response to insulin and epinephrine. Biochemistry 2: 586-592

40. Foster DW (1967) Studies on the ketosis of fasting. J Clin Invest 46: $1283-1296$

41. Owen OW, Reichard GA Jr (1971) Human forearm metabolism during progressive starvation. J Clin Invest 50: 1536-1545

42. Sherwin RS, Kramer KJ, Tobin JD, Insel PA, Liljenquist JE, Berman M, Andres R (1974) A model of the kinetics of insulin man. J Clin Invest $53: 1481-1492$

43. Mondon CE, Olefsky JM, Dolkas CB, Reaven GM (1975) Removal of insulin by perfused rat liver: effect of concentration. Metabolism 24: $153-160$

44. Harding PE, Bloom G, Field JB (1975) Effect of infusion of insulin into portal vein on hepatic extraction of insulin in anesthetized dogs. Am J Physiol 228: 1580-1588

45. Unger RH, Aguilar-Parada E, Müller WA, Eisentraut AM (1970) Studies of pancreatic alpha cell function in normal and diabetic subjects. J Clin Invest 49: 837-848

46. Fisher M, Sherwin RS, Hendler R, Felig P (1976) Kinetics of glucagon in man: effects of starvation. Proc Natl Acad Sci USA 73: $1735-1739$

47. Liljenquist JE, Rabin D (1979) Lack of a role of glucagon in the disposal of an oral glucose load in normal man. J Clin Endocrinol Metab 49: 937-939

48. Bratusch-Marrain P, Waldhäusl W, Grubeck-Loebenstein B, Korn A, Vierhapper H, Nowotny P (1981) The role of diabetogenic hormones on carbohydrate and lipid metabolism following oral glucose loading in insulin dependent diabetics: effects of acute hormone administration. Diabetologia 21: 387-393

49. Williamson JR (1967) Effects of fatty acids, glucagon and anti-insulin serum on the control of gluconeogenesis and ketogenesis in rat liver. Adv Enzyme Reg 5: 229-255

50. Lefebvre P (1977) Glucagon and lipid metabolism. In: Lefebvre PJ, Unger RH (eds) Glucagon: molecular physiology, clinical and therapeutic implications. Pergamon Press, Oxford, pp 109-121

Received: 9 November 1982

and in revised form: 13 May 1983

Professor W. Waldhäusl, M.D.

I. Medizinische Universitätsklinik

Lazarettgasse 14

A-1090 Wien, Austria 